\title{
40. ABO and Lewis Blood Groups in Crab-eating Macaques
}

\author{
By Hachiro NakajIma and Tadamitsu Ogushi \\ Department of Legal Medicine, Tokyo Medical and Dental University \\ (Comm. by Tanemoto FuruhatA, M.J.A., Feb. 12, 1965)
}

Previously, ${ }^{1-4)}$ the present authors examined the blood of the Japanese apes, crab-eating macaques, and green monkeys for their Lewis blood groups and successfuly divided the Japanese apes, as in man, into three groups, i.e. groups $\operatorname{Le}(a+b-), \operatorname{Le}(a-b+)$, and $\operatorname{Le}(a-b-)$. All the Japanese apes tested contained $\mathrm{Le}^{\mathrm{a}}, \mathrm{Le}^{\mathrm{b}}$, and $\mathrm{H}$ substances in their saliva being independent of Lewis groups of the red cells. The $L e^{a}$ substance was also detected in the blood of some individuals among crab-eating macaques, but not in green monkeys.

Subsequently, Wiener, Moor-Jankowski, and Gordon (1964) ${ }^{5}$ tested the saliva from 10 species of non-human primates and found the presence of Lewis $\left(\mathrm{Le}^{\mathrm{a}}\right)$ substance in 7 species, i.e. chimpanzee, orangutan, gibbon, gorilla, baboon, pig-tail monkey, and Celebes black ape.

The present paper gives the results of tests on the blood and submaxillary glands of crab-eating macaques not only for the Lewis groups but also for $\mathrm{ABO}$ groups.

Materials and Methods. Blood of macaque was collected by heart puncture, part of which was placed in a dry-clean test tube and part mixed with acid-citrate-dexitrose solution. Immediately before use, the red cells were washed three times in normal saline. To test the Lewis substances in the serum, it was previously absorbed with human group 0 red cells to eliminate hetero-agglutinin for human red cells. The submaxillary gland was ground in a mortar and saline extract $(10 \% \mathrm{w} / \mathrm{v})$ was prepared. For Lewis group tests, a human anti-Le ${ }^{\mathrm{a}}$

Table I. Summary of ABO group tests on crab-eating macaques

\begin{tabular}{c|c|c}
\hline Number observed & $\begin{array}{c}\text { ABH substances in } \\
\text { submaxillary gland }\end{array}$ & $\begin{array}{c}\text { Group-specific agglutinins } \\
\text { in serum }\end{array}$ \\
\hline 13 & B and H & Anti-A (1: 8-64) \\
\hline 7 & A and H & $\begin{array}{c}\text { Anti-B }(1: 4-128) \\
\text { Anti-B }(1: 8-512) \text { and } \\
\text { weak anti-A (1: 1-2) }\end{array}$ \\
\hline 2 & A, B, and H & Weak anti-A (1: 1-2) \\
4 & & - \\
\hline Total 30 & &
\end{tabular}


serum and a rabbit anti-Le ${ }^{\mathrm{b}}$ serum prepared by immunizing with human Le $(a-b+)$ saliva were used. Human anti-A and anti-B sera and anti$\mathrm{H}$ reagent prepared from Ulex europaeus seeds were used for $\mathrm{ABO}$ group tests. The agglutination, absorption, elution and agglutinationinhibition tests were performed according to the methods described by Nakajima and Miyagi (1964) ${ }^{4}$ and by Nakajima and Hayashida (1963). ${ }^{6)}$

Results. 1) $\mathrm{ABO}$ groups. The saline extract of submaxillary gland of 30 macaques was tested for its $A B O$ substances by the agglutination-inhibition technique using human anti-A and anti-B sera and Ulex anti-H reagent. The results obtained are summarized in table I. The extract of 9 of 30 macaques gave reactions corresponding to group $A, 13$ to group $B$, and the rest to group $A B$, and a rough reciprocal relation seemed to exist between the antigen of gland and the antibody of serum in crab-eating macaque, though it was not so perfect as in man and anthropoid apes.

2) Lewis groups. Thirty macaque blood and 14 submaxillary gland samples of them were examined for their Lewis groups by means of direct agglutination, absorption, elution, or agglutination-inhibition tests with human anti-Le ${ }^{\mathrm{a}}$ and rabbit anti-Le ${ }^{\mathrm{b}}$ sera.

The red cells of two of 30 macaques tested completely absorbed the anti-Le ${ }^{\mathrm{a}}$ agglutinin adjusted to have a titre of $1: 4$ against human

Table II. Results of agglutination and absorption tests of the red cells of crab-eating macaques for Lewis grouping

\begin{tabular}{|c|c|c|c|c|}
\hline \multirow{2}{*}{ Red cells of } & \multicolumn{2}{|c|}{$\begin{array}{l}\text { Agglutination of } \\
\text { red cells with }\end{array}$} & \multicolumn{2}{|c|}{$\begin{array}{l}\text { Titration scores of anti-Lewis } \\
\text { sera after absorption with } \\
\text { macaque red cells*) }\end{array}$} \\
\hline & $\begin{array}{c}\text { anti-Le } \\
\text { (in saline) }\end{array}$ & $\begin{array}{c}\text { anti-Le }{ }^{\mathrm{b}} \\
\text { (in bromelin) }\end{array}$ & anti-Le $e^{a}$ & anti-Le ${ }^{b}$ \\
\hline \multicolumn{5}{|l|}{ Macaque } \\
\hline No. 9 & - & - & 11 & 11 \\
\hline No. 10 & - & ++ & 10 & 8 \\
\hline No. 11 & ++ & - & 0 & 12 \\
\hline No. 13 & - & - & 10 & 11 \\
\hline No. 14 & - & ++ & 10 & 8 \\
\hline No. 19 & ++ & - & 0 & 11 \\
\hline No. 24 & - & + & 10 & 11 \\
\hline \multicolumn{5}{|l|}{ Human controls } \\
\hline $\operatorname{Le}(a+b-)$ & +++ & - & 0 & 11 \\
\hline $\operatorname{Le}(a-b+)$ & - & +++ & 10 & 0 \\
\hline $\operatorname{Le}(a-b-)$ & - & - & 11 & 12 \\
\hline
\end{tabular}

Note: Anti-Lewis sera used for agglutination tests were previously absorbed with No. 9 macaque red cells.

*) Red cells vs, antiserum $=1: 1$. 
$\mathrm{Le}(\mathrm{a}+\mathrm{b}-)$ red cells, and also reduced markedly the Le $\mathrm{Le}^{\mathrm{a}}$ titration score as shown in table II. On the other hand, none of 30 macaque red cell samples significantly reduced the titration score of the anti-Le ${ }^{\mathrm{b}}$ agglutinin for human $\operatorname{Le}(a-b+)$ red cells. The red cells of three of 30 macaques after contact with anti-Le $e^{\mathrm{b}}$ serum, however, yielded eluates with anti-Le ${ }^{\mathrm{b}}$ specificity, indicating the presence on the red cells of the $\mathrm{Le}^{\mathrm{b}}$ substance similar to but not identical with that of man. The two macaque red cell samples, which absorbed the anti-Le agglutinin, and the three macaque red cell samples, which showed positive results in the elution tests with anti-Le ${ }^{b}$ serum, were agglutinated respectively by anti-Le $\mathrm{L}^{\mathrm{a}}$ and anti-Le $\mathrm{e}^{\mathrm{b}}$ sera absorbed with a macaque red cell sample (No. 9) which was confirmed by the absorption and elution tests to be lacking in either $\mathrm{Le}^{\mathrm{a}}$ or $\mathrm{Le}^{\mathrm{b}}$ substances. These agglutinations were specifically inhibited by the human saliva from group Le $(a+b-)$ and/or group $\operatorname{Le}(a-b+)$ individuals but not by the saliva from group Le $(a-b-)$ individuals.

Thus, of the 30 macaques tested, 2 or 7 per cent belonged to group $\operatorname{Le}(a+b-), 3$ or 10 per cent to group $\operatorname{Le}(a-b+)$, and the rest (25 or 87 per cent) to group $\operatorname{Le}(a-b-)$. The frequency of $\operatorname{Le}(a+b-)$ observed in this study on crab-eating macaques was much lower than

Table III. Results of inhibition tests of anti-Lewis sera by saline extracts $(10 \% \mathrm{w} / \mathrm{v})$ of submaxillary glands of crab-eating macaques

\begin{tabular}{|c|c|c|c|c|}
\hline \multirow{2}{*}{$\begin{array}{l}\text { Lewis groups of } \\
\text { red cells }\end{array}$} & \multirow{2}{*}{ Macaque No. } & \multicolumn{3}{|c|}{$\begin{array}{l}\text { Inhibition titres of the extract of } \\
\text { gland for anti- }\end{array}$} \\
\hline & & $\mathrm{Le}^{\mathrm{a}}$ & $\mathrm{Le}^{\mathrm{b}}$ & $\mathrm{H}$ \\
\hline \multirow{2}{*}{$\operatorname{Le}(a+b-)$} & 11 & $1: 2$ & 8 & 256 \\
\hline & 19 & 2 & 0 & 256 \\
\hline \multirow{3}{*}{$\operatorname{Le}(a-b+)$} & 10 & 2 & 8 & 128 \\
\hline & 14 & 4 & 8 & 64 \\
\hline & 24 & 4 & 4 & 128 \\
\hline \multirow{9}{*}{$\operatorname{Le}(a-b-)$} & 16 & 0 & 8 & 128 \\
\hline & 17 & 0 & 1 & 128 \\
\hline & 18 & 1 & 1 & 128 \\
\hline & 20 & 2 & 8 & 256 \\
\hline & 21 & 4 & 2 & 256 \\
\hline & 22 & 0 & 0 & 256 \\
\hline & 23 & 1 & 1 & 128 \\
\hline & 29 & 8 & 1 & 64 \\
\hline & 30 & 1 & 2 & 64 \\
\hline
\end{tabular}

Note: The titres of the antisera used in the tests were previously adjusted to $1: 4$. 
that of the Japanese apes ( 15 or 50 per cent of 30 blood samples; Nakajima, 1962). ${ }^{11}$

The serum of group $\operatorname{Le}(a+b-)$ macaques inhibited anti-Le $e^{a}$, but the serum of group $\operatorname{Le}(a-b+)$ or $\operatorname{Le}(a-b-)$ macaques did not. The $\mathrm{Le}^{\mathrm{a}}$ negative macaque red cells treated in vitro with the macaque serum containing the $\mathrm{Le}^{\mathrm{a}}$ substance became $\mathrm{Le}^{\mathrm{a}}$ positive, though the reaction of the red cells with anti-Le ${ }^{a}$ serum was weaker than that of the fresh red celled of $\operatorname{Le}(a+b-)$ macaques. This suggests that the Lewis substance on the red cells of macaques might be secondarily taken up from the serum, as in man."

Table III shows the results of inhibition tests of human anti-Lea, rabbit anti-Le $\mathrm{e}^{\mathrm{b}}$, and Ulex anti-H agglutinins by saline extract $(10 \%$ $\mathrm{w} / \mathrm{v}$ ) of the submaxillary glands of 14 macaques. As illustrated in the table, most of the samples tested inhibited both anti-Le ${ }^{a}$ and anti$\mathrm{Le}^{\mathrm{b}}$ agglutinins being independent of Lewis groups of the red cells. All the 14 samples also inhibited the anti-H agglutinin, and there was no relation among the inhibition titres for anti-Le ${ }^{\mathrm{a}}$, anti-Le ${ }^{\mathrm{b}}$, and anti$\mathrm{H}$ agglutinins.

Summary. Blood and submaxillary gland of crab-eating macaques were tested for their $\mathrm{ABO}$ and Lewis blood groups. All the macaques tested contained A and/or B substances in their glands and a rough reciprocal relation seemed to exist between the antigen of gland and the antibody of serum. In testing the red cells, crab-eating macaques could be divided into three groups in Lewis blood groups, as in man, and it was suggested that the $\mathrm{Le}^{\mathrm{a}}$ substance on the red cells might be taken up from the serum. The submaxillary glands contained both $\mathrm{Le}^{\mathrm{a}}$ and $\mathrm{Le}^{\mathrm{b}}$ substances being independent of Lewis groups of the red cells.

Acknowledgements. We wish to thank Drs. H. Shimojo, M. Hara, and A. Hagiwara of Murayama Branch, National Institute of Health of Japan for supplying us with blood and gland of macaques.

\section{References}

1) Nakajima, H.: Jap. J. Legal Med., 16, 143 (1962) (in Japanese).

2) Ogushi, T.: Jap. J. Legal Med., 16, 140 (1962) (in Japanese).

3) Nakajima, H.: Jap. J. Legal Med., 17, 210 (1963) (in Japanese).

4) Nakajima, H., and M. Miyagi: Jap. J. Legal Med., 18, 76-80 (1964).

5) Wiener, A. S., J. Moor-Jankowski, and E. B. Gordon: J. Forensic Med., 11, 67-83 (1964).

6) Nakajima, H., and Y. Hayashida: Jap. J. Legal Med., 17, 341-346 (1963).

7) Sneath, J. S., and P. H. Sneath: Nature, 176, 172 (1955). 